\title{
MENINGKATKAN KEMAMPUAN KOMUNIKASI MATEMATIK SISWA SMK MELALUI PEMBELAJARAN SOFTWARE CABRI 3D
}

\author{
Alpha Galih Adirakasiwi \\ Program Studi Pendidikan Matematika, FKIP Universitas Singaperbangsa Karawang \\ Jl. H.S. Ronggowaluyo Telukjambe, Karawang \\ email: alphagalih1988@gmail.com
}

\begin{abstract}
Abstrak
Penelitian ini bertujuan untuk mengetahui peningkatan kemampuan komunikasi matematik melalui pembelajran software cabri 3D pada materi dimensi tiga. Metode penelitian yang digunakan adalah metode penelitian quasi eksperimen dengan disain kelompok kontrol postes. Unit-unit eksperimen dilakukan di dua kelas yang masingmasing menggunakan pembelajaran dengan software cabri $3 D$, dan pembelajaran konvensional. Subjek penelitian adalah 30 orang siswa kelas XI SMK di kota Karawang. Instrumen yang digunakan untuk mengukur kemampuan komunikasi matematik berupa tes tertulis bentuk uraian. Hasil analisis data menunjukan bahwa pembelajaran dengan menggunakan software cabri $3 D$ memberikan pengaruh berupa peningkatan terhadap kemampuan komunikasi matematik pada materi dimensi tiga. Nilai rata-rata siswa kelas kontrol adalah 20,73, sedangkan nilai rata-rata setelah diberikan perlakuan adalah 24,97
\end{abstract}

Kata kunci : Kemampuan Komunikasi Matematik, Software Cabri 3D

\section{Abstract}

This research purpose of this article is to know the increase of the ability of mathematical communication based on the learning software cabri on 3D material. Research method used is quasi experiment with group design control post. The experimental units is two classes which use learning with software cabri $3 D$, and conventional learning. The subject of this research is thirty students class XI SMK in Karawang. Instrument used to measure mathematical communication ability is written test in explanation form. The result of data analysis shows that learning with using software cabri $3 D$ gave influence to the increasing of mathematical communication ability on three dimension material. The average score of control group is 20,73, and the average score of treatment group is 24,97

Keywords $\quad$ : Ability Mathematic Communication, Software Cabri 3D 


\section{A. PENDAHULUAN}

Perkembangan teknologi informasi saat ini telah menjadi pusat perhatian di berbagai bidang kehidupan, salah satunya yakni bidang pendidikan. Dengan hadirnya ICT dalam dunia pendidikan bisa membawa dampak positif untuk meningkatkan kualitas pembelajaran. Penggunaan ICT pada pembelajaran di sekolah telah menjadi salah satu pilihan untuk menyampaikan konsep yang bersifat abstrak menjadi lebih konkrit. Seperti halnya, dalam Pemelajaran matematika berfungsi untuk menyampaikan konsep yang bersifat abstrak menjadi lebih konkrit.

\section{Dalam pembelajaran} matematika terutama materi geometri banyak bentuk bangun ruang yang harus dipelajari siswa dan selanjutnya sering disebut dimensi tiga, misalnya sudut dan bidang, proyeksi, jarak, sudut antara garis dan bidang, dan irisan. Konvensionalnya pada pokok bahasan dimensi tiga seorang guru merasa kesulitan untuk menjelaskan kepada siswa. Dikarenakan materi ini membutuhkan kemampuan visualisasi relatif yang tinggi. Sebagai contoh, saat siswa menjumpai soal dimensi tiga, dimana siswa diminta untuk menghubungkan titik tengah 2 diagonal ruang suatu balok. Jika tidak menggunakan alat peraga atau media pembelajaran, tentu tidak semua siswa mampu memvisualisasikannya. Saat itulah para siswa dituntut untuk membayangkan sebuah bangun untuk memecahkan soal. Dengan kemampuan visualisasi yang relatif rendah, siswa agak sulit untuk mengkomunikasikan unsur-unsur pada bangun ruang tersebut ke dalam bahasa matematika sendiri. Untuk itu akan lebih efektif dalam proses pengajaran materi dimensi tiga dijelaskan melalui visualisasi bangun ruang yang memungkinkan dapat diamati serta dikonstruksi penurunan sifat-sifatnya secara bersama melalui pengukuran langsung dan akurat dengan berbantuan software.

Salah satu software khusus untuk materi geometri yaitu software cabrie 3D. Software cabri 3D merupakan media pembelajaran berbasis IT yang dapat memudahkan siswa dalam menggambarkan bangun tiga dimensi yang ukurannya seperti benda asli.

Penggunaan software cabri $3 D$ terhadap pembelajaran matematika dapat diharapkan berdampak positif terhadap kemampuan komunikasi matematika. Karena dengan software cabri 3D siswa dilatih untuk mentransformasikan masalah nyata ke dalam bahasa matematika. Seperti contoh, siswa disajikan melalui gambar bangun ruang balok jika jaring-jaring balok diperlihatkan. Maka, siswa dapat mengkomunikasikan bangun ruang balok dengan bahasa mereka sendiri dari jaring-jaring balok tersebut.

Berdasarkan latar belakang di atas peneliti merumusakan judul penelitian sebagai berikut Meningkatkan Kemampuan 
Komunikasi Matematik Siswa SMK Melalui Pembelajaran Software Cabri 3D.

\section{B. KAJIAN TEORI}

1. Kemampuan Komunikasi Matematik

Komunikasi merupakan bagian yang sangat penting pada matematika dan pendidikan matematika. Komunikasi dapat diartikan sebagai sebagai proses penyampain pesan dari seeorang kepada orang lain baik secara langsung (lisan) maupun melalui media. Menurut Darhim menyatakan dalam proses komunikasi dikenal tiga jenis komunikasi yaitu sebagai berikut: (1) Komunikasi searah ialah komunikasi yang hanya terjadi dari guru ke siswa; (2) Komunikasi dua arah adalah bentuk komunikasi yang terjadi antara guru dengan siswa; (3) Komunikasi banyak arah (multi arah) ialah komunikasi yang melibatkan banyak unsur, yaitu antara guru dengan siswa atau antara siswa dengan siswa atau antara siswa dengan guru. Komunikasi matematik merupakan salah satu tujuan pemelajaran matematika dan menjadi salah satu standar kompetensi lulusan siswa sekolah dari pendidikan dasar sampai menengah sebagaimana tertuang dalam Permen 22 Tahun 2006 tentang Standar Kompetensi Kelulusan dalam bidang Matematika yang berhubungan dengan komunikasi matematik.

Seperti dijelaskan oleh Turmudi (2009:74) komunikasi secara matematika karena matematika seringkali diberikan dalam simbol, komunikasi tertulis dan komunikasi lisan yang berisi gagasan matematika yang tidak selalu dikenal sebagai bagian penting dalam pendidikan matematika.

\section{Komunikasi matematik} memegang peranan penting dalam proses pemelajaran matematika. Karena tanpa komunikasi matematik yang baik maka pemelajaran matematika tidak akan mampu berkembang. Dalam

Principles and Standart for School Mathematics mendeklarasikan program pembelajaran di kelas-kelas TK sampai SMK harus memberi kesempatan kepada siswa untuk mengorganisasi dan mengkonsolidasikan pemikiran dan ide matematika dengan cara mengkomunikasikannya,mengkomuni kasikan pemikiran matematika secara logis dan jelas kepada teman sejawatnya, gurunya, dan orang lain,menganalisis dan mengevaluasi pemikiran matematika orang lain; dan menggunakan bahasa matematika untuk menyatakan ide-ide dengan tepat .

Hal ini menunjukkan bahwa komunikasi matematik bagian yang tidak terpisahkan dari matematika. Siswa pada tingkat sekolah menengah harus berpandangan bahwa matematika melibatkan kegiatan kesanggupan atau kecakapan siswa untuk menyatakan dan menafsirkan gagasan matematis secara lisan, tertulis, atau mendemonstrasikan apa 
yang ada dalam persoalan matematika.

Menurut Vermont Departemen of Education (Mahmudi, 2009) Komunikasi melibatkan 3 aspek yaitu: (1) Menggunakan bahasa matematika secara akurat dan menggunakannya untuk mengkomunikasikan aspekaspek penyelesaian masalah; (2) Menggunakan representasi matematika secara akurat untuk mengkomunikasikan penyelesaian masalah; dan (3) Mempresentasikan penyelesaian masalah yang terorganisasi dan terstruktur dengan baik. Komunikasi matematik yang dimaksud pada penelitian ini mengkomunikasikan hasil-hasil pemikirannya kepada orang lain baik secara lisan ataupun tertulis sehingga secara tidak langsung mereka akan berlatih untuk menjelaskan, mengemukakan pendapat, serta mempertanggungjawabkan pendapatnya.

\section{Software Cabri 3D}

Cabri 3D merupakan salah satu software matematika dengan berbantuan komputer yang bisa menampilkan variasi bentuk geometri dimensi tiga. Software ini merupakan pengembangan dari cabri geometri II yang dipakai untuk metari geometri dimensi dua. Software cabri 3D diproduksi oleh Cabrilog untuk belajar dan mengajarkan matematika khususnya yang berhubungan dengan geometri. Cabri teknologi lahir di laboratorium penelitian Perancis, Centre National de la Recherche
Scientifique (CNRS) dan Joseph Fourier Grenoble University.

Cabri 3D sangat bermanfaat untuk belajar dan mengajar geometri karena dapat membantu siswa untuk mampu mengembangkan konsepkonsep geometri, mengeksplorasi hubungan geometris serta mengembangkan kemampuan keruangan siswa. Menurut Accascina \&Rogora (2006) berpendapat Cabri $3 D$ is a potentiaaly very useful software for learning and teaching $3 D$ geometry. The dynamic nature of the digital diagrams produced with provides a useful aid for helping students better develop concept images of geometry concept. Dapat diartikan cabri 3D merupakan perangkat lunak yang sangat berguna untuk belajar dan mengajar geometri. Sifat dinamis dari digital diagram menyediakan bantuan yang berguna untuk membantu siswa agar mendapatkan pemahaman lebih baik tentang konsep gambar dari konsep geometri. Program ini pada awalnya dikembangkan oleh Jean Marie Laborde sebagai ketua researching interactive tools for teaching mathematics untuk membuat geometri dua dimensi lebih mudah belajar dan lebih menyenangkan untuk mengajar. Software visualisasi 3D, seperti software cabri $3 D$ versi 2 menyediakan 3 manfaat untuk siswa dan guru yaitu peangkat lunak yng diberikan dapat memperluas pemahaman siswa terhadap 3D, karena memungkinkan siswa mengungkapkan hubungan antara 
bentuk-bentuk lain yang sulit untuk mengeksplorasi; kemampuan pengukuran dengan menggunakan bagian dari perangkat lunak memberikan kesempatan untuk menghubungkan geometri menjadi aljabar dan pembuktian tertulis; perangkat lunak visualisasi 3D dapat membantu guru dan siswa untuk memperluas generalisasi dari dua dimensi menjadi tiga dimensi. Melalui program ini penggunanya bisa menganimasi atau memanipulasi objek geometri, akan sangat berbeda jika dibandingkan objek geometri tersebut hanya pada papan.

Menurut Achmad (2009: 10) Beberapa kemampuan dan kelebihan serta kelemahan cabri $3 D$ yang dapat teridentifikasi adalah: (1) Dapat mengerjakan komputasi aljabar; (2) Dapat mengerjakan komputasi analisis; (3) Dapat mengerjakan berbagai mechanical dan optical (physical objects); (4) Mempunyai banyak perintah bawaan dalam library dan paket-paket untuk pengerjaan matematika secara luas;

Mempunyai fasilitas untuk pengerjaan pengeplotan dan animasi untuk grafik baik dimensi dua maupun dimensi tiga; (6) Mempunyai suatu antarmuka berbasis worksheet; (7) Mempunyai fasilitas untuk membuat dokumen dalam beberapa format; Mempunyai fasilitas bahasa pemrograman yang memudahkan pemahaman konsep siswa; (9) Sangat baik untuk melatih fluency (kelancaran), fleksibility (keluwesan), dan elaboration (keterperincian); (10)
Hasil sketsanya lebih baik daripada menggunakan autograph dan maple.

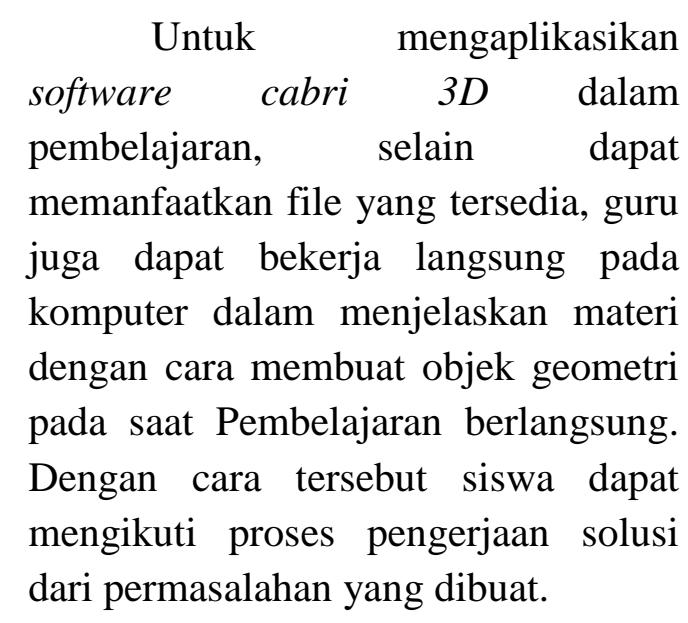

\section{METODE PENELITIAN}

Metode penelitian yang digunakan adalah metode penelitian quasi eksperimen dengan disain kelompok kontrol postes. Desain penelitian yang digunakan dalam penelitian ini adalah Post Test Only Control Group Design yaitu desain penelitian yang hanya mengukur pasca perlakuan dan melibatkan kelompok kontrol. Unit-unit eksperimen dilakukan di dua kelas yang masingmasing menggunakan pembelajaran dengan software cabri 3D, dan pembelajaran konvensional. Dengan demikian disain eksperimen yang dipilih adalah sebagai berikut :

\section{X \\ Gambar 1 \\ Desain Penelitian}

Dengan keterangan sebagai berikut :

$\mathrm{X}$ : Perlakuan dengan Pembelajaran software cabri 3D

O : Tes Kemampuan Komukasi Matematik 
Penelitian ini dilaksanakan selama 8x3 jam pelajaran untuk masing-masing kelas eksperimen dan kelas kontrol. Instrumen yang digunakan untuk mengukur kemampuan komunikasi matematik berupa tes tertulis bentuk uraian.

Populasi dalam penelitian adalah seluruh siswa kelas XI di salah satu kota Karawang. Pengambilan sampel dari dua kelas yang sudah terpilih, dipilih secara acak satu kelas pembelajaran software cabri 3D dan konvensional.

Tes ini terdiri dari 8 butir soal uraian. Penyusunan tes ini mengacu pada level analisis, sintesis dan evaluasi dari jenjang kognitif pada taksonomi Bloom. Tujuan penyusunan soal ini untuk mengukur kemampuan mentransformasikan masalah nyata ke dalam bahasa matematika, menjelaskan ide situasi dan relasi matematika secara lisan dan tulisan, membaca suatu representasi matematika dan mengungkapkan kembali suatu uraian matematika dalam bahasnya sendiri. Berikut adalah kisi-kisi tes kemampuan komunikasi matematik.

Tabel 1. Kisi-Kisi Tes Kemampuan Komunikasi Matematik

\begin{tabular}{llll}
\hline Indikator & $\begin{array}{l}\text { Materi } \\
\text { Ajar }\end{array}$ & $\begin{array}{l}\text { Jenjang } \\
\text { Kognitif }\end{array}$ & $\begin{array}{l}\text { No. } \\
\text { Soal }\end{array}$ \\
\hline $\begin{array}{l}\text { Menjelaskan ide, } \\
\text { situasi dan relasi } \\
\text { matematika secara }\end{array}$ & Proyeks & C4 & 4 \\
lisan dan tulisan & & & \\
\hline Mentransformasik & Perband & C6 & $2,5,7$ \\
\hline
\end{tabular}

\begin{tabular}{llll}
\hline $\begin{array}{l}\text { an masalah nyata } \\
\text { ke dalam Bahasa } \\
\text { matematka }\end{array}$ & $\begin{array}{l}\text { ingan } \\
\text { volume }\end{array}$ & & \\
\hline $\begin{array}{l}\text { Membaca suatu } \\
\text { representasi }\end{array}$ & $\begin{array}{l}\text { Volume } \\
\text { bangun }\end{array}$ & C6 & 1,6 \\
matematika & ruang & & \\
\hline $\begin{array}{l}\text { Mengungkapkan } \\
\text { kembali suatu }\end{array}$ & Jarak & C5 & 3,8 \\
$\begin{array}{l}\text { uraian matematika } \\
\text { dalam Bahasa }\end{array}$ & & & \\
sendiri & & & \\
\end{tabular}

\section{HASIL DAN PEMBAHASAN}

Adapun untuk mengetahui apakah sampel-sampel penelitian ini berasal dari populasi yang kemampuan awal matematikanya sama, peneliti menggunakan data nilai hasil ulangan harian materi sebelumnya pada semester I. Deskripsi data nilai ulangan harian dari kedua kelompok disajikan pada Tabel 2 berikut ini.

Tabel 2

Sekor Terendah, Skor Tertinggi, Rerata dan Deviasi Standar Kemampuan Awal Matematik Siswa

\begin{tabular}{cccccc}
\hline $\begin{array}{c}\text { Kelompo } \\
\mathbf{k}\end{array}$ & $\begin{array}{c}\mathbf{S} \\
\mathbf{M I}\end{array}$ & $\begin{array}{c}\mathbf{X}_{\mathbf{m i}} \\
\mathbf{n}\end{array}$ & $\begin{array}{c}\mathbf{X}_{\mathbf{m a}} \\
\mathbf{k s}\end{array}$ & $\overline{\mathbf{X}}$ & $\mathbf{s}$ \\
\hline Eksperi & 10 & 45,0 & 87,0 & 64,8 & 8,1 \\
men & 0 & 0 & 0 & 0 & 8 \\
\hline Kontrol & 10 & 41,5 & 85,5 & 64,1 & 8,2 \\
& 0 & 0 & 0 & 9 & 4 \\
\hline
\end{tabular}

Dari Tabel 2 tampak bahwa skor rata-rata kedua kelompok tidak berbeda signifikan. Skor rata-rata kelas eksperimen sebesar 64,80 $(64,80 \%$ dari skor ideal), dan kelompok kontrol sebesar 64,19 $(64,19 \%$ dari skor ideal). Dengan demikian dapat dikatakan bahwa tidak ada perbedaan kemampuan awal 
matematik siswa antara kelas

eksperimen dan kelas kontrol.

\begin{tabular}{|c|c|c|c|c|c|c|}
\hline \multirow{3}{*}{$\begin{array}{c}\text { Kema } \\
\text { mpua } \\
\text { n }\end{array}$} & \multirow{3}{*}{$\begin{array}{l}\text { Skor } \\
\text { ideal }\end{array}$} & \multirow{3}{*}{$\begin{array}{l}\text { Data } \\
\text { Stat }\end{array}$} & \multicolumn{4}{|c|}{ Pembelajaran } \\
\hline & & & \multicolumn{2}{|c|}{$\begin{array}{l}\text { Software } \\
\text { cabri } 3 D\end{array}$} & \multicolumn{2}{|c|}{ Konvensional } \\
\hline & & & $\mathrm{N}$ & Posttes & $\mathrm{N}$ & Postes \\
\hline \multirow[t]{2}{*}{ KM } & 34 & $\begin{array}{c}\text { Rerat } \\
\text { a }\end{array}$ & 30 & $\begin{array}{c}24,97 \\
73,44^{*}\end{array}$ & 30 & $\begin{array}{c}20,73 \\
60,97 *\end{array}$ \\
\hline & & SD & & 4,986 & & 4,433 \\
\hline
\end{tabular}

Selanjutnya pada Tabel 3 di bawah ini disajikan deskripsi data postes kemampuan komunikasi matematik serta siswa berdasarkan pembelajaran.

\section{Tabel 3. Kemampuan Komunikasi Matematik Berdasarkan Pembelajaran}

Keterangan : KM : komunikasi Matematik *(\%) dari Skor Ideal

Berdasarkan Tabel 3 terlihat bahwa rerata hasil postes kemampuan komunikasi matematik siswa yang mengikuti pembelajaran dengan software cabri 3D (sebesar 26,70 atau $78,52 \%$ dari skor ideal) lebih tinggi dibanding yang mengikuti pembelajaran konvensional (sebesar 19,30atau 56,76\% dari skor ideal), terjadi perbedaan sebesar $21,76 \%$. Dapat dilihat juga bahwa simpangan baku skor siswa yang mengikuti pembelajaran software cabri $3 D$ (sebesar 4,07) lebih rendah dibanding simpangan baku skor siswa yang mengikuti pembelajaran konvensional (sebesar 3,36), maka dapat diartikan bahwa skor kemampuan komunikasi matematik siswa yang mengikuti pembelajaran dengan software cabri $3 D$ lebih seragam dibanding yang mengikuti pembelajaran konvensional.

Postes Stem-and-Leaf Plot for

Pembelajarab $=$ eksperimen

Frequency Stem \& Leaf .001 .

$5.00 \quad 1.56789$

$6.00 \quad 2.011244$

$13.00 \quad 2.5555566677889$

6.003 .001333

Stem width: $\quad 10$

Each leaf: 1 case(s)

\section{Gambar 1. Stem and Leaf dengan Pembelajaran Software Cabri 3D}

Hasil stem and leaf pada gambar 1 diatas menggunakan stem width 10 dan each leaf 1 case. Berdasarkan stem and leaf tersebut, bisa dilihat bahwa skor kemampuan siswa di kelompok eksperimen yang tertinggi adalah 33 dan terendah adalah 15 . Median skor siswa berada diantara data ke-15 dan ke-16 yaitu 25.00

$$
\begin{aligned}
& 3.00 \quad 1.344 \\
& 10.00 \quad 1.5678888899 \\
& 9.00 \quad 2.011111233 \\
& 7.00 \quad 2.5556677 \\
& 1.003 .1
\end{aligned}
$$

Stem width: $\quad 10$

Each leaf: 1 case(s)

\section{Gambar 2. Stem and Leaf dengan}

\section{Pembelajaran Konvensional}

Hasil stem and leaf pada gambar 2 diatas menggunakan stem 
width 10 dan each leaf 1 case. Berdasarkan stem and leaf tersebut, bisa dilihat bahwa skor kemampuan siswa di kelompok kontrol yang tertinggi adalah 31 dan terendah adalah 13. Median skor siswa berada diantara data ke-15 dan ke-16 yaitu 21.00 .

Untuk melihat apakah terdapat perbedaan yang signifikan tentang kemampuan komunikasi matematik siswa setelah mengikuti pembelajaran software cabri 3D dan konvensional, maka dilakukan uji perbedaan ratarata. Untuk menguji perbedaan ratarata, akan diuji terlebih dahulu normalitas data.

Pada pengujian normalitas, digunakan

uji Kolmogorov-Smirnov (KS). Dari perhitungan uji normalitas dengan menggunakan software SPSS 17 diperoleh hasil seperti disajikan pada Tabel 4

Tabel 4. Hasil Uji Normalitas Data

Skor Tes Kemampuan Komunikasi

Matematik Berdasarkan Pendekatan

Pembelajaran

Tests of Normality

Pembelajaran Kolmogorov-Smirnov ${ }^{\mathrm{a}}$

\begin{tabular}{llll}
\cline { 2 - 4 } & Statistic & df & Sig \\
\hline Software & $\mathbf{. 1 3 6}$ & $\mathbf{3 0}$ & $\mathbf{. 1 6 4}$
\end{tabular}

Cabri 3D

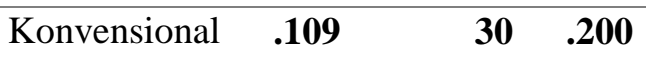

a. Liliefors Significance Correction

* This is a lower bound of the true significance.

Kriteria Pengujian : Jika Sig. > 0,05 maka sampel berdistribusi normal.
Berdasarkan Tabel 4 terlihat untuk setiap pembelajaran baik pembelajaran software cabri 3D maupun pembelajaran konvensional memiliki nilai Sig. > 0,05. Hal ini menandakan bahwa kedua sampel berdistribusi normal dapat dilihat pada gambar 3 data berdistribusi normal

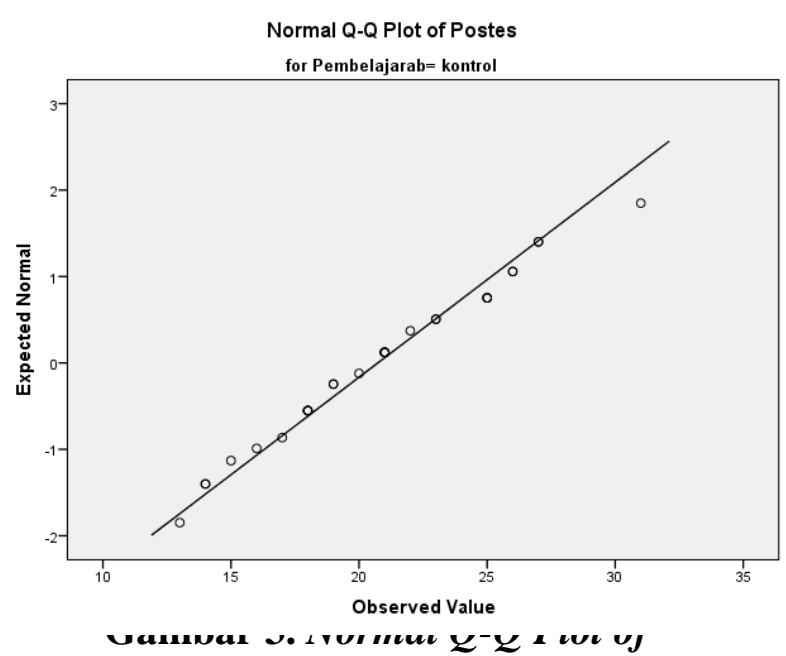

Postes Pada Pembelajaran Software cabri $3 D$

Sedangkan pada kelas kontrol dengan pembelajaran konvensional berditribusi normal dapat dilihat pada gambar 4

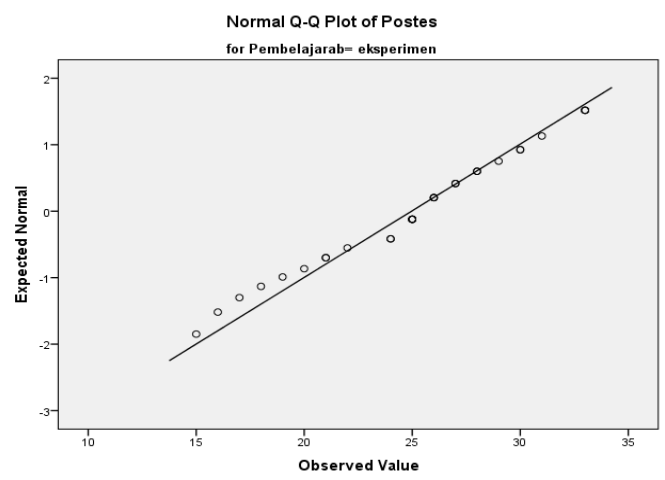

Gambar 4. Normal Q-Q Plot of Postes Pada Pembelajaran

\section{Konvensional}

Selanjutnya dilakukan uji homogenitas varians, hasil uji 
homogenitas menggunakan software SPSS 17 disajikan pada Tabel 5

Tabel 5. Hasil Uji Homogenitas Varians Kemampuan Komunikasi Matematik

\begin{tabular}{lllll}
\hline & $\begin{array}{l}\text { Levene } \\
\text { Statistic }\end{array}$ & df1 & df2 & Sig. \\
\hline $\begin{array}{l}\text { Based on } \\
\text { Mean }\end{array}$ & .157 & 1 & 58 & .693 \\
\hline $\begin{array}{l}\text { Based on } \\
\text { Median }\end{array}$ & .164 & 1 & 58 & .687 \\
\hline $\begin{array}{l}\text { Based on } \\
\text { Median and } \\
\text { with }\end{array}$ & .164 & 1 & 56.31 & .687 \\
adjusted df & & & 2 & \\
\hline $\begin{array}{l}\text { Based on } \\
\text { trimmed } \\
\text { mean }\end{array}$ & .145 & 1 & 58 & .704 \\
\hline
\end{tabular}

Kriteria Pengujian : Jika Sig. > 0,05 maka kedua varians data homogen.

Pada Tabel 5 terlihat nilai sig $=0,157$ > 0,05 maka dapat disimpulkan bahwa kedua varians data tersebut homogen. Setelah skor dinyatakan normal dan homogen maka selanjutnya dilakukan uji kesamaan dua rat-rata kelompok eksperimen dan kelompok kontrol dengan menggunakan uji $\mathrm{t}$ pada $\alpha=$ 0,05 dengan kriteria pengujian: terima Ho, jika sig $>\alpha=0,05$.

\section{Pengujian hipotesis :}

Hipotesis penelitian untuk kemampuan komunikasi matematik adalah "Kemampuan komunikasi matematik siswa SMK yang mengikuti pembelajaran dengan menggunakan software cabri 3D lebih baik dibandingkan yang mengikuti pembelajaran konvensional". Sebagai konsekuensi statistik dari hipotesis penelitian tersebut, diuji hipotesis nol (Ho) sebagai berikut :

Hipotesis:

$$
\begin{aligned}
& \mathrm{H}_{0}: \mu_{1}=\mu_{2} \\
& \mathrm{H}_{\mathrm{A}}: \mu_{1}>\mu_{2}
\end{aligned}
$$

Kriteria Pengujian : Jika Sig. > 0,05

maka $\mathrm{H}_{0}$ diterima.

\section{Tabel 6. Hasil Uji Perbedaan Rata-} rata Tes Kemampuan KomunikasMatematik Independent Samples Test t-test for Equality of Means

\begin{tabular}{llll} 
& $\mathrm{T}$ & $\mathrm{df}$ & $\begin{array}{l}\text { Sig. } \\
(2- \\
\text { tailed })\end{array}$ \\
\cline { 2 - 4 } & & & .000 \\
\hline $\begin{array}{l}\text { Equal } \\
\text { variances } \\
\text { assumed }\end{array}$ & 3.475 & 58 & \\
\hline $\begin{array}{l}\text { Equal } \\
\text { variances } \\
\text { not assumed }\end{array}$ & 3.475 & 57.216 & .000 \\
\hline
\end{tabular}

Berdasarkan Tabel 6 terlihat nilai sig. $=0,000<0,05$, ini berarti Ho ditolak. Dengan demikian dapat disimpulkan bahwa kemampuan komunikasi matematik siswa SMK yang mengikuti pembelajaran dengan menggunakan software cabri 3D lebih baik dibandingkan yang mengikuti pembelajaran konvensional.

\section{E. PENUTUP}

Hasil penelitian yang telah dilakukan menunjukkan bahwa penggunaan software cabri $3 D$ dapat meningkatkan kemampuan komunikasi matematik siswa, diantaranya siswa dapat termotivasi dalam belajar matematika karena cara 
menampilkan pelajaran yang tidak konvensional, maksudnya adalah dengan menggunakan softwar cabri $3 D$

Matematika yang menjadi salah satu mata pelajaran yang wajib dimuat dalam kurikulum pendidikan dasar dan menengah. Matematika dapat diartikan sebuah bahasa untuk terus ditingkatakan khususnya dalam kemampuan komunikasi matematik. oleh karena itu, dalam meningkatkan kemampuan komunikasi matematik siswa terus diupayakan. Hasil penelitian ini dapat digunakan sebagai dasar untuk diadakan penelitian lebih lanjut mengenai penggunaan softwre cabri $3 D$ dalam pengajaran matematika.

\section{DAFTAR PUSTAKA}

Accascina, Giuseppe, \& Enrico, R. 2006. Using Cabri 3D for Teaching Geometry. International Journal for Techonolgy in Mathematics Education, Volume 13(1):1-10

Buchori, A. Jurnal "Potensi Program Cabri 3D untuk mendukung Pembelajaran Geometri Analit di Perguruan Tinggi".Program Studi pendidikan Matematika FPMIPA IKIP PGRI Semarang Depdiknas. 2006. Kurikulum Tingkat Satuan Pendidikan. Jakarta: Depdiknas

Mahmudi, A. 2009. Jurnal MIPMIPA UNHALU. "Komunikasi

dalam Pemelajaran
matematika".Volume 8,
Nomor 01.

Turmudi, 2009. Landasan Filsafat dan Teori Pemelajaran matematika Berparadigma Eksploratif dan Investigatif. Jakarta : PT. Leuser Cita Pustaka 